\title{
THEORETICAL SUBSTANTIATION OF SPECIFICS OF FORMATION OF UKRAINIAN NATIONAL MORAL AND ETHICAL VALUES OF THE PERSON AT A YOUNG SCHOOL AGE
}

\author{
MARIA KOPCHUK-KASHETSKA
}

\begin{abstract}
The article provides a theoretical substantiation of the specificity of formation of Ukrainian national moral and ethical values of younger students' personality. The comparative analysis of existing points of view on the nature of moral and ethical values and their functional significance in the formation of personality is carried out. The content of national moral and ethical values as a historical property of the people, which determine its mentality and national character, is revealed. Ukrainian national moral and ethical values are as imperative entities, developed and formed, which exist throughout the life of the Ukrainian people, they have an intransitive character, moral requirements, regulate the regulatory function and use the necessary knowledge regarding their free species and personality. Ukrainian ethnology has shown that it is possible to preserve Ukrainian national moral and ethical factors by growing up in childbirth, defining enrichment and updating the most up-to-date elementary education. The younger school age becomes more sensitive in the development of moral and ethical and the qualities that determine the patterns, moral behavior is formed. The goals and content of the process of formation of moral and ethical values of junior students by means of the sciences are specified through adequate tasks, which reflect the main directions of educational influence on the personality of the student. In the formation of the system of moral and ethical values in the younger students pedagogical efforts and actions of the primary school teacher should be directed to the development of moral and ethical needs and motives of behavior, formation of ethical knowledge and education of ethical feelings, development of appropriate skills, habits, as well as strengthening of will qualities. In formation of moral and ethical values of people do not matter indirect educational actions, but the attitude of the pupil to them, transformation of external influences into the internal moral and psychological sphere of personality, internal perception of external influences, including educational ones.
\end{abstract}

Keywords: personality, junior high school students, moral and ethical values, Ukrainian national moral and ethical values, moral requirements, moral behavior, Ukrainian Ethnology.

\section{INTRODUCTION}

At the present stage of the democratic development of the state, upholding its sovereign interests and national revival, the problem of educating the younger generation on the basis of moral and ethical values by the means of ethnology, the affirmation of people's ethical ideals and models of moral behavior is actualized. 
The priority in the construction of the New Ukrainian school is the task of forming a system of universal values of students - moral and ethical (dignity, honesty, justice, care, respect for life, respect for oneself and other people) and socio-political (freedom, democracy, cultural diversity, respect for the mother tongue and culture, patriotism, respect for the environment, respect for the law, solidarity, responsibility) [11].

Ukrainian Ethnology

It is well known that it is possible to save children by discovering enrichment and updating the most up-to-date education and attaining primary school that has found people with socio-cultural backgrounds that are constantly used by the Ukrainian population in their own practices.

Appeal to the natural sciences is an arbitrary factor in the revived Ukrainian culture, it is preserved using its own national identity, forming a national identity, moral and ethical importance. Ethnic science, which covers various aspects of Ukrainian culture, remains in the past also a people's morality, embodied in moral and ethical qualities in real life. Formed in the process of life of the people, moral and ethical values reflect positive experience and heritage in the field of morality, outlook, orient to the moral norms and principles of life, enshrined in the traditions, customs, beliefs that are supported in the way of life.

"At the same time, depending on the relationship of a man with the world, the object of perception of values, which are divided into material and spiritual ones; depending on the level of generality into the concrete and the abstract ones; depending on the way of identifying - into the situational and the stable ones. A quite common classification of values divides them depending on the criterion of membership: personal (individual), group (collective) social, national and universal values" [4, p. 52].

\section{ANALYSIS AND DiscUSSION}

Reflecting the needs of both the individual and society as a whole, moral and ethical values are time-tested, generally accepted and are not altered by the influence of private views, interests and circumstances. Considering the notion of moral and ethical values as derived from values, Z. Gipters in the "Cultural Dictionary Directory" characterizes value in the context of the life of society and the individual as a common standard, which is directed education [8, p. 293-294].

Since moral and ethical values play an important role in regulating behavior and attitudes towards the outside world in the "Vocabulary", edited by V. V. Radul, their content is revealed through the activity-interested attitude of the individual towards the world and himself. In particular, attention is paid to the problematic realization of moral needs in life [9, p. 292].

Moral and Ethical Values - Imperative formations are produced and formed throughout the life of the Ukrainian people. They are of a transient nature, preserve the continuity of moral requirements, perform a regulatory function in the relationship of people and become personally relevant as a result of their choice and internalization of the individual in the process of education.

In various popular sources, moral and ethical values are recorded in the commandments, tips, instructions, which substantiate the need to observe moral norms and principles of behavior, determine the strategy and tactics of life on the examples of folk heroes, act as a form of social influence.

Due to the multifaceted nature of the concept of "moral and ethical values" there are different approaches in defining its structure, interrelations and interactions of components that broaden and complement each other.

In examining the structure of higher values, I. Bekh draws attention to the different order of the "determinants" from the point of view of the social sphere - their carrier: from the family cell to the whole society; the possible contradiction of the translated values, which can lead to personal conflicts; varying degrees of imperativeness for their acceptance by the subject [1, p. 10].

According to O. Vyshnevsky, the structure of the moral and ethical values of the Ukrainian people is determined by the structure of society, which consistently includes: man - family - community nation (state) - all humanity [5, p. 200-201]. 
N. Gannusenko, K. Chorna reveal the pedagogical function of values as orienting and directing the vital activity of the individual, as well as acting as the "axis of consciousness", a condition of its selfrealization and behavior. To structural components they include ethical literacy, procedural activity, value-semantic, reflective components [2, p. 6-7].

O. Sukhomlynska attributes to the moral and ethical values normative ideas about good and evil, justice, beautiful and ugly about the purpose of man, human ideals, norms, principles of life, which are of moral importance and affect the general social life. Differentiating moral and ethical values from the main human values, virtues, partial moral values, the scientist points to the presence in each positive value its negative equivalent, which is also included in the structure of values, but as its negatively significant component.

Although the process of engaging children in the moral and ethical values of the Ukrainian people is a long one, the younger school age is considered by us to be the most sensitive, since it is during this period that the foundations of worldview an and morality, the need for moral and ethical values and qualities is realized, models are defined, moral behavior is formed.

In modern pedagogical science, the younger school age covers the period of study of a child in primary school from the first to the fourth grade (from 6 to 10 years). Although at different times, the age of younger students was defined differently, which was related to the beginning of schooling: from 9 years in the last century; from 8-7 years in Soviet times. Also, the term of study at school from 3 to 4 years and so on.

At a young school age, the development of a system of moral values is accompanied by the justification of purpose, content of activity. The probability of obtaining a positive result educational activity increases significantly if the latter aims at the formation of certain moral and ethical values, set as a goal.

The general goals of the process of formation of moral and ethical values should be pedagogically instrumental, aimed at practical implementation. The content of moral and ethical education of younger students is focused on the implementation of common educational goals based on the ethnographic approach.

The goals and content of the process of formation of moral and ethical values of junior students by means of the sciences are specified through adequate tasks, which reflect the main directions of educational influence on the personality of the student. It is said that in the formation of the system of moral and ethical values in the younger students pedagogical efforts and actions of the primary school teacher should be directed to the development of moral and ethical needs and motives of behavior, the formation of ethical knowledge and education of ethical feelings, the development of appropriate skills, habits and habits, as well as strengthening the strong-willed qualities.

Purposeful formation of moral and ethical values of the personality is carried out in organized adult educational activity and communication, where the activity of the younger schoolboy's personality is manifested and his moral needs and motives of behavior are formed. It is pedagogically organized activity and communication creates those educational situations and moral relationships that provide the influence and formation of moral and ethical values of younger students.

The peculiarity of the formation of moral and ethical values of the Ukrainian people among younger students is that they are perceived as certain norms and general principles of behavior offered to them by adults. However, even good knowledge of these norms, which determines the cognitive component in the formation of moral and ethical values $n$ children, cannot ensure their firm manifestation in behavior. The internalization of the moral and ethical values of the Ukrainian people through the assimilation of moral norms implies not only the accumulation of knowledge relevant content, but also their refraction through the prism of the child's consciousness - the formation of own moral experience, attitudes to behavioral stereotypes and moral models that are offered, as a result of emotional experience and the transfer of moral and ethical values of the Ukrainian people into the inner world of personality, individual consciousness and behavior.

At a young school age, the social functions and roles of children change, and their moral relationships with the outside world and other people greatly expand. Younger students are actively 
involved in the life of the school, actively communicate with adults, peers make some connections with them. During this age period, the child intensively assimilates the moral and ethical rules, norms and principles inherent in the Ukrainian people, which are accompanied by the formation of related moral habits and skills in the behavior of the respective moral qualities. The change in the status of the child necessitates the cultivation of a certain system of moral and ethical values, which would allow them to adapt quickly to new social conditions and help further moral growth.

The moral and ethical values of younger students are reflected in their attitude towards other people. This sphere of life of primary school students is realized through contacts with other people, through communicatio The specificity of communication lies in the fact that it is an activity of personality aimed at knowing people and interacting with them. In communication, younger students have the opportunity, unlike other activities, to maximize their moral qualities, to master the moral and ethical standards of behavior and interaction with other people, to gain individual moral experience, to evaluate the actions and actions of adults and peers to understand its correctness.

The formation of the system of moral and ethical values $n$ children of 1-4 grades is determined by the moral experience of the Ukrainian people with the conditions of education and upbringing, the influence of the macro- and microenvironment as well as the types of activities and communication in which they are involved in their life activities.

An important component of an individual's ethical behavior is an act, that is, a single act of his or her socially significant activity. In the act, in its internal structure, the unity of subjective, individual factors (needs, interests, goals, motives of actions) and external - circumstances that are not dependent on the will of the performer, as well as socially significant consequences of the action, act as the focus.

A moral act as an act of objectifying a certain moral and ethical value or group of values is in turn regarded as a peculiar value, which carries new nuances and properties. The moral choice determines the specifics of moral behavior: younger students have to choose a certain model of behavior from several possible ones. It is at this point that the child begins to be guided by the moral and ethical values of the people, based on already existing experience. The child can either help a friend or not; may take advantage of, or decline, all of the privileges accorded to it; to tell the truth whether to remain silent or to say "I do not know" etc. The immoral behavior of children of this age is not punishable by law, and therefore it may seem that there is freedom to choose behavior, regardless of its moral and ethical side. But even at a young school age, free choice in favor of the moral and ethical values of the Ukrainian people is governed by internal instigators: conscience, dignity, as well as public opinion, the opinion of parents and teachers.

In the formation of the moral and ethical values of the Ukrainian people, the primary school pupils have the importance not of indirect educational actions, but of the pupil's attitude towards them, transformation of external influences into the internal moral and psychological sphere of the individual, internal perception of external influences, including educational ones. In the process of education and upbringing of younger students selective attitude to them is formed a which L.Bozhovych explains as the observation of children, the ability to compare opinions and the actions of others, as well as their own with the learned norms and rules of behavior, which shapes one's own view, inner position in the choice and appropriation of certain moral and ethical values.

The effectiveness of the process of formation of moral and ethical values of a person depends on timely identification and resolution of contradictions by changing and improving the pedagogical conditions of raising children. However, in the educational process, contradictions do not only overcome, but can be specially created by the teacher. On the state of formation of moral and ethical values of younger students negatively affected by pedagogical omissions and mistakes, which are:

- authoritarian methods of upbringing, forcibly imposing own value system;

- formal approach to parenting;

- neglectance of folk traditions and pedagogical achievements in educational practice;

- lack of desire to improve business;

- focus on relativistic programs in spite of the need of value education of children;

- ignorance of the specifics of the younger school age; 
- separation of educational efforts of family and school;

- inconsistency between the words of adults and their behavior;

- lack of own moral experience;

- conflict or juxtaposition of moral and ethical values in the child's life practice;

- focus not on the moral and ethical values of the Ukrainian people, but on easily attainable goals;

- loss of historical memory.

The process of formation of moral and ethical values of primary school students is of a step character and is carried out in the direction of enrichment and complication not only of the above structural components, but also their content filling. We should take into account the regularity: the formation of some, more complex in structure and content moral and ethical values, which depends on the formation of others - less complex qualities. [7, p. 188].

The moral realm of younger students is a hierarchy interconnected in a single whole, personal formation of moral and ethical values.

\section{CONCLUSIONS}

"While teaching universal and national values to pupils, we should recognise such factors as the priority ones: taking into account the natural abilities of the student, ethno-psychological and individual characteristics, and cognitive interests. These must be focussed primarily on the study of our own historical experience for the development of high civic culture; democracy in the organisation of educational activities at the national ground; and combine family and regional-national traditions, customs and rituals popular in the mountainous region for filling the living space with the elements of spirituality" [4, p. 65].

We can conclude that the basis of the traditional system of moral and ethical education of Ukrainians is the transfer of customary rules and norms of behavior, principles of folk and morality, awareness of moral preceptions of childhood, development of deep convictions. We also find urgent formation of positive moral and psychological traits, motivation to society and activities, as well as overcoming the negative behaviors in which the customs and traditions of the people, which are important levers and means of modern education, and play an important role. It is significant enrichment at the expense of the ideas of ethnology, in particular Ukrainian ethno-pedagogy. The norms that have been nurtured on Ukrainian lands for centuries are the means of formation and development of moral and ethical values of the student's personality. The formation of moral and ethical values of children by the means of sciences, taking into account the specifics of the younger school age is extremely relevant.

\section{REFERENCES}

[1] Bekh I.D. Upbringing of a Personality. Works in two volumes. Volume 1. Lybid, Kyiv, 2003. (in Ukrainian)

[2] Bekh I.D. Program of the Course "Ethics" for 5-6 grades of general secondary school. Shkilnyj Svit, 15 (239) (2004), 5-18. (in Ukrainian)

[3] Budnyk O. Ethnic Pedagogy of Economic Education of Schoolchildren. Scientific and methodical manual. IvanoFrankivsk, 2005. Available at: http://194.44.152.155/elib/local/878.pdf (in Ukrainian)

[4] Budnyk O., Mazur P. The Hierarchy of Values among Young People from Schools in the Mountainous Regions (Comparative study on the example of Poland and Ukraine. The New Educational Review, 47 (1) (2017), 53-65. doi: 10.15804/tner.2017.47.1.04

[5] Vyshnevskyi O.I. Theoretical Basis of Contemporary Ukrainian Pedagogy. Manual for students of higher education institutions. Kolo, Drohobych, 2003. (in Ukrainian) 
[6] Kyrychok V.A. Humane Treatment of the Child: a methodological guide for teachers. Infodruk, Kyiv, 2004. (in Ukrainian)

[7] Kopchuk-Kashetska M.S. Formation of Moral and Ethnic Values of Junior Students by Means of Ukrainian Folkstudy: monograph. "Jaryna", Ivano-Frankivsk, 2017. (in Ukrainian)

[8] Hipters Z. Cultural Dictionary-Directory. Profesional, Kyiv, 2006. (in Ukrainian)

[9] Radula V. (Ed.) Social and Pedagogical Dictionary. "EksOb", Kyiv, 2004. (in Ukrainian)

[10] Tsiuniak O. Peculiarities of family upbringing under the conditions of mountain rural area. Mountain school of the Ukrainian Carpathians, 11 (2014), 233-235. (in Ukrainian)

[11] Bibik N.M. (Ed.) New Ukrainian School: Teacher Advisor. Litera LTD, Kyiv, 2018. (in Ukrainian)

Address: Maria Kopchuk-Kashetska, Vasyl Stefanyk Precarpathian National University, 57, Shevchenko Str., Ivano-Frankivsk, 76018, Ukraine.

E-mail: mariia.kopchuk-kashetska@pnu.edu.ua

Received: 16.01.2020; revised: 28.02.2020.

Копчук-Кашецька Марія. Теоретичне обгрунтування специфіки формування українських національних морально-етичних цінностей особистості в молодшому шкільному віці. Журнал Прикарпатського університету імені Василя Стефаника, 7 (1) (2020), 171-176.

У статті подане теоретичне обгрунтування специфіки формування українських національних морально-етичних цінностей особистості молодших школярів. Проведено порівняльний аналіз існуючих точок зору на природу морально-етичних цінностей та їх функціонального значення в формуванні особистості. Розкрито зміст національних морально-етичних цінностей як історичного надбання народу, що визначають його ментальність та національний характер. Українські національні морально-етичні цінності трактуються як імперативні утворення, вироблені і сформовані впродовж усієї історії життєдіяльності українського народу, мають неперехідний характер, зберігають наступність моральних вимог, виконують регулятивну функцію та набувають особистісної значущості за умов їх вільного вибору та прийняття особистістю у процесі виховання. Українське народознавство розглядається важливим засобом формування українських національних морально-етичних цінностей молодого покоління, покдиканим збагатити і оновити зміст сучасної початкової освіти. Молодший шкільний вік визначено як найбільш сенситивний у розвитку морально-етичних цінностей особистості, оскільки саме в цей період закладаються основи світогляду і моральності, усвідомлюеться необхідність морально-етичних цінностей і якостей, визначаються взірці, формується моральна поведінка. Цілі і зміст процесу формування морально-етичних цінностей молодших школярів засобами народознавства конкретизуються через адекватні завдання, які відображають основні напрями виховного впдиву на особистість учня. Доведено, що у формуванні системи морально-етичних цінностей здобувачів початкової освіти педагогічні зусилля і дії вчителя мають бути спрямовані на розвиток морально-етичних потреб і мотивів поведінки, формування етичних знань і виховання етичних почуттів, вироблення відповідних умінь, навичок і звичок, а також зміцнення вольових якостей. 3'ясовано, що у розвитку морально-етичних цінностей українського народу у мододших школярів значення мають не опосередковані виховні дії, а передусім ставлення вихованця до них, трансформація зовнішніх впливів у внутрішню морально-психологічну сферу особистості, внутрішне сприйняття зовнішніх впливів, у тому числі і виховних.

Кдючові слова: особистість, молодші школярі, морально-етичні цінності, українська національні морально-етичні цінності, моральні вимоги, моральна поведінка, українське народознавство. 